\author{
Z. A. Mikhaylovskaya ${ }^{a^{*}}$, E. S. Buyanova ${ }^{a}$, \\ S. A. Petrova ${ }^{b}$ A. A. Nikitina ${ }^{a}$ \\ ${ }^{a}$ Ural Federal University, \\ 19 Mira St., Ekaterinburg, 620002, Russia \\ ${ }^{b}$ Institute for Metallurgy, Ural Branch of the Russian Academy of Sciences, \\ 101 Amundsen St., Ekaterinburg, 620016, Russia \\ E-mail: zozoikina@mail.ru
}

\title{
Sheelite-related strontium molybdates: synthesis and characterization
}

The present research is devoted to the cationic-deficient $\mathrm{SrMoO}_{4}$-based sheelite-related complex oxides. The doping with bismuth to A sublattice and codoping with bismuth and vanadium (to $A$ and $B$ sublattices, respectively) were discussed. The X-Ray powder diffraction and infrared spectroscopy were used to investigate structural characteristics of the complex oxides. $\ln \mathrm{Sr}_{1-1.5 x} \mathrm{Bi}_{x} \mathrm{MoO}_{4}$, a superstructural ordering was observed. Conductivity and dielectric loss of ceramic samples are measured using alternating current.

Keywords: sheelite; strontium molybdates; dielectric materials.

Received: 25.10.2018. Accepted: 17.12.2018. Published: 31.12.2018.

(C) Mikhaylovskaya Z. A., Buyanova E. S., Petrova S. A., Nikitina A. A., 2018

\section{Introduction}

Scheelite-type complex oxides are quite interesting research objects because flexibility of substitutions in these systems leads to variety of their compositions, structure types and properties. Ideal scheelite-related oxides have a general formula $\mathrm{ABO}_{4}$ and consist of $\mathrm{A}^{\mathrm{n}+}$ cations and $\left(\mathrm{BO}_{4}\right)^{\mathrm{n}-}$ anions. A-site ions are coordinated with eight oxygen ions, and B-site ions are coordinated with four oxygen ion. Each site can be occupied simultaneously by different ions with various oxidation states; additional interstitial positions and vacancies lead to the deviation from the general formula. A lot of scheelite-type complex oxides are used as materials for scintillation detectors, lasers $[1,2]$, ionic conductors [3], phosphors [4], photocatalysts [5], and microwave dielectrics [6]. The regula- tion of the desired properties of sheelite-related materials can be provided by varying the quantity of the dopant, its nature, the ratios between dopants and the presence of additional vacancies or interstitial positions in the structure. For example, a substitution of A-site ions with $\mathrm{Me}^{+3}$ in $\mathrm{ABO}_{4}$ complex oxide can be described in two ways: (1) a formation of $\mathrm{A}_{1-\mathrm{x}} \mathrm{Me}^{+3}{ }_{\mathrm{x}} \mathrm{BO}_{4+\mathrm{x} / 2}$ phases, where electroneutrality is provided by the interstitial oxygen ions; (2) a formation of $\mathrm{A}^{+2}{ }_{1-1.5 \mathrm{x}} \mathrm{Me}_{\mathrm{x}}^{+3} \Phi_{0.5 \mathrm{x}} \mathrm{MoO}_{4}$ (or $\mathrm{A}_{1-1.5 \mathrm{x}}^{+2} \mathrm{Me}_{\mathrm{x}}^{+3} \mathrm{MoO}_{4}$ ) phases containing cationic vacancies $\Phi$. The first way of substitution was detected for $\mathrm{Pb}(\mathrm{Mo} / \mathrm{W}) \mathrm{O}_{4}$ $[7,8]$ and $\mathrm{Ca}(\mathrm{Mo} / \mathrm{W}) \mathrm{O}_{4}[9]$ parent compounds. The second way was described for rare-earth substituted $\mathrm{Ca}(\mathrm{Mo} / \mathrm{W}) \mathrm{O}_{4}$, $\mathrm{Sr}(\mathrm{Mo} / \mathrm{W}) \mathrm{O}_{4}$ and $\mathrm{Cd}(\mathrm{Mo} / \mathrm{W}) \mathrm{O}_{4}[10-12]$. 
As a result, cationic vacancies $\Phi$ and their ordering are additional structural factors influencing physico-chemical properties. Another way of the substitution of $\mathrm{A}$ positions is codoping with $\mathrm{Me}^{+3}$ and $\mathrm{Me}^{+1}$ or $\mathrm{Me}^{+5}$ ions, which leads to the formulae $\mathrm{A}_{1-x} \mathrm{Me}_{0.5 x}^{+1} \mathrm{Me}^{+3}{ }_{0.5 x} \mathrm{BO}_{4}$ [13] and $\mathrm{A}_{1-x} \mathrm{Me}^{+3}{ }_{x} \mathrm{~B}_{1-x} \mathrm{Me}^{+5}{ }_{x} \mathrm{O}_{4}$, respectively [14]. The present research is devoted to the $\mathrm{Bi}$-doped strontium molybdate $\mathrm{SrMoO}_{4}$. The existence of $\mathrm{Sr}_{1-1.5 \mathrm{x}} \mathrm{Bi}_{\mathrm{x}} \mathrm{MoO}_{4}$ series was shown by Sleight and coauthors [15], who synthesized the complex oxide $\mathrm{Sr}_{0.88} \mathrm{Bi}_{0.08} \mathrm{MoO}_{4}$ (tetragonal symmetry, Sp. Gr. $\left.I 4_{1} / a\right)$ and described its good catalytic properties [15]. $\mathrm{Sr}_{1-1.5 x} \mathrm{Bi}_{x} \mathrm{MoO}_{4}$ family

\section{Experimental}

Synthesis of $\mathrm{Sr}_{1-1.5 x} \mathrm{Bi}_{x} \mathrm{MoO}_{4}(0 \leq x \leq 0.45)$, $\mathrm{Sr}_{1-x} \mathrm{Bi}_{x} \mathrm{Mo}_{1-x} \mathrm{~V}_{x} \mathrm{O}_{4}(0 \leq x \leq 0.4)$, $\mathrm{Sr}_{1-1.5 x} \mathrm{Bi}_{x} \mathrm{Mo}_{1-y} \mathrm{~V}_{y} \mathrm{O}_{4-d}(0<x \leq 0.4,0<y \leq 0.2)$ were synthesised by conventional solid state methods from $\mathrm{SrCO}_{3}(98.5 \%), \mathrm{Bi}_{2} \mathrm{O}_{3}$ (99.9\%), $\mathrm{V}_{2} \mathrm{O}_{5}(98.5 \%)$ and $\mathrm{MoO}_{3}(99.0 \%)$. Stoichiometric amounts of dried precursors were weighed and mixed in an agate mortar as dispersion in ethanol. Mixtured powders were pelletized and heated at 550$650{ }^{\circ} \mathrm{C}$ with regrinding and repelletizing. Time of each heating was $\sim 10$ hours, the total time of heating was $\sim 30$ hours.

$\mathrm{X}$-ray powder diffraction data were obtained on a DRON-3 with $\mathrm{Cu} \mathrm{Ka}$ monochromatic radiation in the range of $5-75^{\circ}$ of $2 \theta$. IR FT spectrometry measurements has not been described yet, while Bi-doped calcium molybdates have been intensively researched as microwave dielectric [16] or pigments [14]. The basic characteristic and structure types of $\mathrm{SrMoO}_{4}$ are similar to those of $\mathrm{CaMoO}_{4}$, so the Bi-doped strontium molybdates should possess similarly promising properties. In addition, Bi-doping of strontium molybdates is expected to lead to decrease of the unit cell, resulting from the significant changes in B-sublattice. Therefore, the objects of the present work are $\mathrm{Sr}_{1-1.5 x} \mathrm{Bi}_{x} \mathrm{MoO}_{4}$, $\mathrm{Sr}_{1-x} \mathrm{Bi}_{x} \mathrm{Mo}_{1-x} \mathrm{~V}_{x} \mathrm{O}_{4}, \mathrm{Sr}_{1-1.5 x} \mathrm{Bi}_{x} \mathrm{Mo}_{1-y} \mathrm{~V}_{y} \mathrm{O}_{4-d}$ solid solutions and their structure and properties.

were carried out at Nicolet 6700 with attenuated total reflection attachment. Density of powder samples was measured by hydrostatic weighting. For conductivity measurements, the ceramic pellets of 10 $\mathrm{mm}$ in diameter and ca. $2.5 \mathrm{~mm}$ thickness were covered by Pt. Impedance spectra were obtained in two-electrode measurement cell on LCR-819 and Elins Z-3000 impedance spectrometers, over the frequency ranges $1 \mathrm{~Hz}$ and $3 \mathrm{MHz}$ to $10 \mathrm{~Hz}$, respectively, at stabilised temperatures from $c a .25^{\circ} \mathrm{C}$ to $c a .625^{\circ} \mathrm{C}$. Data presented correspond to the second cooling run. Data were modelled using equivalent electrical circuits with the Zview software (Version 2.6b, Scribner Associates, Inc.).

\section{Results and discussion}

Synthesis of $\mathrm{Sr}_{1-1.5 \mathrm{x}} \mathrm{Bi}_{\mathrm{x}} \mathrm{MoO}_{4}$ yielded samples with the structure of $\mathrm{Sr}_{0.88} \mathrm{Bi}_{0.08} \mathrm{MoO}_{4}$ [15], up to $x=0.2$ (Sp.gr. $\left.I 4_{1} / a\right)$. At $0.2<$ $x<0.4$ additional peaks in the small angle range are evident; for the $x>0.45 \mathrm{com}$ position additional peaks in the pattern can be identified as $\mathrm{Bi}_{3} \mathrm{MoO}_{12}$. We supposed that $0.2<x \leq 0.4$ compositions have superstructural ordering caused by ordering of cationic vacancies (Fig. 1).

As a result, in the XRPD data for $0.2<x \leq 0.4$ compositions all peaks can be successfully indexed using a tetragonally ordered supercell $a_{\text {sup }}=\sqrt{5} a_{\text {sub}}$, 
$c_{\text {sup }}=c_{\text {sub }}$ (where sup and sub subscripts denote the super- and subcell, respectively) in $I 4_{1} / a$ space group (Fig. 2). Compositional dependence of the unit cell parameters for $\mathrm{Sr}_{1-1.5 x} \mathrm{Bi}_{x} \mathrm{MoO}_{4}$ compositions are shown in Fig. 2, where the linear chemical compression is caused by the substitution of the bigger cation with the smaller one (ionic radii $r_{\mathrm{Sr}^{2+}}=1.26 \AA, r_{\mathrm{Bi}^{3+}}=1.17 \AA$ [17]). The measurements of density showed that experimental density is equal to the theoretical (X-ray) one to within the $2-3 \%$ of absolute values.

Synthesis of $\mathrm{Sr}_{1-\mathrm{x}} \mathrm{Bi}_{\mathrm{x}} \mathrm{Mo}_{1-\mathrm{x}} \mathrm{V}_{\mathrm{x}} \mathrm{O}_{4}$ results in the two-phase samples that consist of $\mathrm{BiVO}_{4}$ (monoclinic) and $\mathrm{SrMoO}_{4}$ phases. In contrast, $\mathrm{Ca}_{1-x} \mathrm{Bi}_{x} \mathrm{Mo}_{1-x} \mathrm{~V}_{x} \mathrm{O}_{4}$ solid solutions are observed for $0 \leq x \leq 0.9$ [14]. One possible reason was that the dopants influence differently the composition and structure of strontium and calcium molybdates. The simultaneous presence of $\mathrm{Bi}$ and

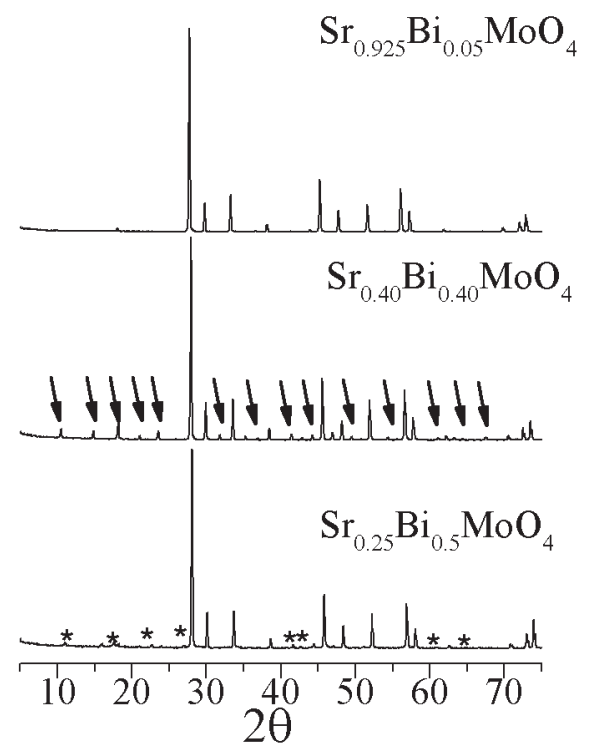

Fig. 1. X-ray diffraction profiles for selected $\mathrm{Sr}_{1-1.5 x} \mathrm{Bi}_{x} \mathrm{MoO}_{4}$ compositions. Arrows and asterisks indicate superlattice and $\mathrm{Bi}_{2} \mathrm{Mo}_{3} \mathrm{O}_{12}$ reflections, respectively
$\mathrm{V}$ in $\mathrm{Ca}_{1-x} \mathrm{Bi}_{x} \mathrm{Mo}_{1-x} \mathrm{~V}_{x} \mathrm{O}_{4}$ leads to the expansion of the unit cell of a complex oxide due to the replacement of calcium with bismuth and compression of the unit cell due to the replacement of molybdenum with vanadium; as a result, the unit cell changes slightly [14] (ionic radii $r_{\mathrm{Ca}^{2+}}=1.12 \AA, r_{\mathrm{V}^{5+}}=0.54 \AA$, $r_{\mathrm{Mo}^{6+}}=0.41 \AA$ [17]). In contrast, in $\mathrm{Sr}_{1-x} \mathrm{Bi}_{x-}$ $\mathrm{Mo}_{1-x} \mathrm{~V}_{x} \mathrm{O}_{4}$ both of $\mathrm{Bi}$ and $\mathrm{V}$ lead to compression of the unit cell, making it unstable. It can be assumed that such compression of the unit cell leads to the decrease of the distance between $\left[\mathrm{BO}_{4}\right]^{n-}(\mathrm{B}=\mathrm{Mo}, \mathrm{V})$ clusters and, consequently, to the increase of repulsion between them. As a result, the destruction of $\mathrm{Sr}_{1-\mathrm{x}} \mathrm{Bi}_{\mathrm{x}} \mathrm{Mo}_{1-\mathrm{x}} \mathrm{V}_{\mathrm{x}} \mathrm{O}_{4}$ system is observed. Creating an oxygen deficiency in the crystal lattice provides distortion in $\mathrm{BO}_{4}$ tetrahedra and formation of $\left[\mathrm{BO}_{4}\right]-$ $\left[\mathrm{BO}_{3}\right]^{n-}$-type bonds through common oxygen atoms. This can be realized by changing

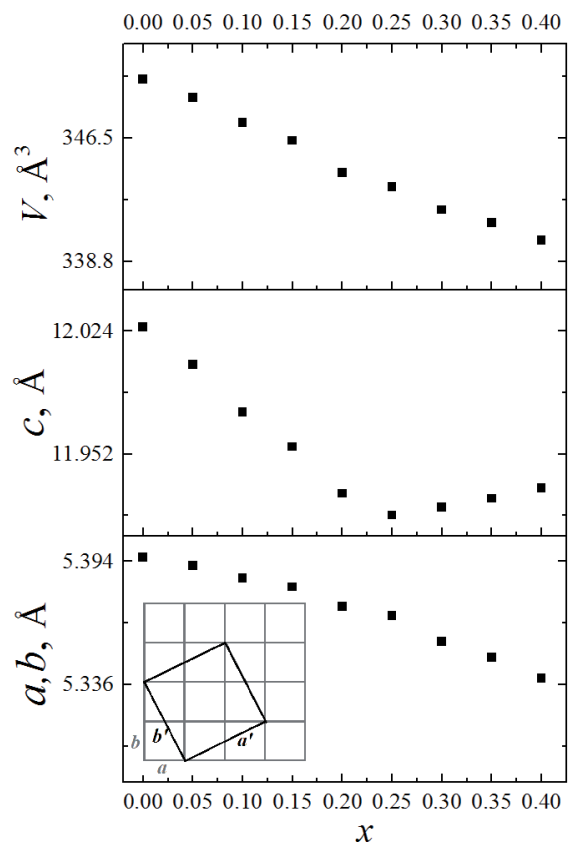

Fig. 2. Compositional variation of unit cell parameters in $\mathrm{Sr}_{1-1.5 \mathrm{x}} \mathrm{Bi}_{\mathrm{x}} \mathrm{MoO}_{4}$; super $\left(a^{\prime}, b^{\prime}\right)$ and sub $(a, b)$ - cells in $\mathrm{Sr}_{1-1.5 x} \mathrm{Bi}_{x} \mathrm{MoO}_{4}$ series (inset) 
the composition of strontium molybdate to $\mathrm{Sr}_{1-1.5 x} \mathrm{Bi}_{x} \mathrm{Mo}_{1-y} \mathrm{~V}_{y} \mathrm{O}_{4-d}$.

It was expected that low concentration of bismuth would not provide a proper compression of the unit cell and singlephase samples would not be observed even at small $y$. But high concentration of bismuth can provide an efficient compression of the unit cell and the possibility of doping with vanadium. In fact, we observed such trend. For $x=0.1$ in $\mathrm{Sr}_{1-1.5 x} \mathrm{Bi}_{x} \mathrm{Mo}_{1-y} \mathrm{~V}_{y} \mathrm{O}_{4-d}$ no single-phase samples was obtained, for $x=0.2$ only $y=0.05$ composition is single phase, for $x=0.3$ and $x=0.4$ singlephase compositions were observed at $y=$ $0.05-0.1$ and $0.05-0.2$, respectively. In this research, the maximum concentration of vanadium was not determined exactly, but the general trend is clear.

In the Table 1, the unit cell parameters of the single-phase samples are shown. When $x$ is fixed and $y$ increases or when $y$ is fixed and $x$ increases, a general compression of the unit cell is observed. The presence of vanadium in the structure leads to the absence of cationic ordering, and no additional peaks in X-ray diffraction profiles of $x=0.3-0.4$ are observed. Unfortunately, it has proved impossible to accurately refine the oxide ion positions in the unit cell using a Rietveld approach, due to dominance of the X-ray scattering by the cations in this system and only neutron diffraction can refute or confirm the specified theory about the $\left[\mathrm{BO}_{4}\right]-\left[\mathrm{BO}_{3}\right]^{n-}$-type bond formation.

Powders of the $\mathrm{Sr}_{1-1.5 x} \mathrm{Bi}_{x} \mathrm{MoO}_{4}$ compositions were characterized by IR FT spectroscopy (Fig. 3). Several adsorption bands in the range of $950-500 \mathrm{~cm}^{-1}$ were detected. According to Basiev [18] sheelite-related compound $\mathrm{ABO}_{4}$ consists of $\left[\mathrm{MoO}_{4}\right]^{2-}$ clusters and isolated $\mathrm{A}^{2+}$ ions and, as a result, characteristic absorption bands can be assigned only to the vibrations in $\left[\mathrm{MoO}_{4}\right]^{2-}$ clusters [19]. Strong absorption bands in the range $940-550 \mathrm{~cm}^{-1}$ are related to $\mathrm{O}-\mathrm{Mo}-\mathrm{O}$ stretches of the

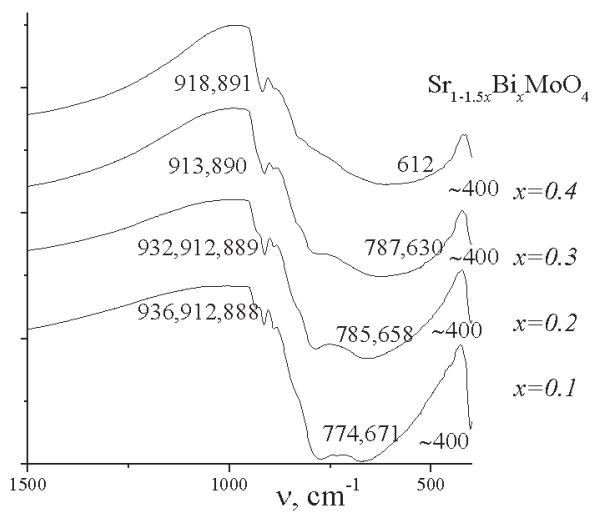

Fig. 3. IR FT spectra of the $\mathrm{Sr}_{1-1.5 \mathrm{x}} \mathrm{Bi}_{\mathrm{x}} \mathrm{MoO}_{4}$ compositions

Table 1

Unit cell parameters of $\mathrm{Sr}_{1-1.5 x} \mathrm{Bi}_{x} \mathrm{Mo}_{1-y} \mathrm{~V}_{y} \mathrm{O}_{4}(0.1<x<0.4,0.05<y<0.2)$ compositions

\begin{tabular}{c|c|c|c|c}
\hline Composition & $a, \AA$ & $b, \AA$ & $c, \AA$ & $V, \AA^{3}$ \\
\hline $\mathrm{Sr}_{0.7} \mathrm{Bi}_{0.2} \mathrm{Mo}_{0.95} \mathrm{~V}_{0.05} \mathrm{O}_{4}$ & 5.367 & 5.367 & 11.935 & 343.78 \\
\hline $\mathrm{Sr}_{0.7} \mathrm{Bi}_{0.2} \mathrm{Mo}_{0.9} \mathrm{~V}_{0.1} \mathrm{O}_{4}$ & 5.363 & 5.363 & 11.961 & 344.02 \\
\hline $\mathrm{Sr}_{0.55} \mathrm{Bi}_{0.3} \mathrm{Mo}_{0.95} \mathrm{~V}_{0.05} \mathrm{O}_{4}$ & 5.353 & 5.353 & 11.896 & 340.87 \\
\hline $\mathrm{Sr}_{0.55} \mathrm{Bi}_{0.3} \mathrm{Mo}_{0.9} \mathrm{~V}_{0.1} \mathrm{O}_{4}$ & 5.348 & 5.348 & 11.896 & 340.24 \\
\hline $\mathrm{Sr}_{0.55} \mathrm{Bi}_{03} \mathrm{Mo}_{0.8} \mathrm{~V}_{0.2} \mathrm{O}_{4}$ & 5.335 & 5.335 & 11.907 & 338.90 \\
\hline $\mathrm{Sr}_{0.4} \mathrm{Bi}_{0.4} \mathrm{Mo}_{0.95} \mathrm{~V}_{0.05} \mathrm{O}_{4}$ & 5.342 & 5.342 & 11.826 & 337.48 \\
\hline $\mathrm{Sr}_{0.4} \mathrm{Bi}_{0.4} \mathrm{Mo}_{0.9} \mathrm{~V}_{0.1} \mathrm{O}_{4}$ & 5.326 & 5.326 & 11.885 & 337.13 \\
\hline $\mathrm{Sr}_{0.4} \mathrm{Bi}_{0.4} \mathrm{Mo}_{0.8} \mathrm{~V}_{0.2} \mathrm{O}_{4}$ & 5.318 & 5.318 & 11.868 & 335.64
\end{tabular}


$\mathrm{MoO}_{4}$ tetrahedron. Additional absorption band near $425-400 \mathrm{~cm}^{-1}$ can also be assigned to the deformational vibrations of O-Mo-O bands. In the IR FT spectra, the general shifting of absorption bands is observed. The same trend was observed for $\mathrm{Ca}_{1-1.5 x} \mathrm{Bi}_{x} \mathrm{MoO}_{4}$ [16]; in both cases it is caused by the deformation of $\mathrm{MoO}_{4}$ tetrahedra resulting from the presence of cationic vacancies.

Conductivity measurements of $\mathrm{Sr}_{1-1.5 x} \mathrm{Bi}_{\mathrm{x}} \mathrm{MoO}_{4}$ ceramic showed very high resistivity of samples (Fig. 4). A slight increase of conductivity is observed for the samples with superstructural ordering $(0.2<x<0.45)$ and two-phase samples $(x>0.45)$.

Changing of dielectric loss tangent $(\operatorname{tg} \delta)$ was measured at the range of 303$903 \mathrm{~K}$ at cooling at the fixed frequency of $1 \mathrm{kHz}$ using the parallel $\mathrm{R}_{\mathrm{p}}+\mathrm{C}$ model (series connected $\mathrm{R}_{\mathrm{s}}$ and Ls were shown to be negligible). The $\operatorname{tg} \delta$ vs temperature curves of $\mathrm{Sr}_{1-1.5 \mathrm{x}} \mathrm{Bi}_{\mathrm{x}} \mathrm{MoO}_{4}$ compositions are shown at Fig. 5. The acceptable dielectric losses $(\operatorname{tg} \delta<0.1)$ of $\mathrm{Sr}_{1-1.5 x} \mathrm{Bi}_{x} \mathrm{MoO}_{4}$ compositions were observed for temperatures below $\sim 573 \mathrm{~K}$, while $\operatorname{tg} \delta$ decreases with $x$ values until $x=0.3$. Then, at $x>0.3, \operatorname{tg} \delta$ increases, probably because of structural ordering of the samples.

For $\mathrm{Sr}_{1-1.5 x} \mathrm{Bi}_{x} \mathrm{Mo}_{1-y} \mathrm{~V}_{y} \mathrm{O}_{4-d}$ compositions we observed a significant growth in conductivity in comparison with $\mathrm{Sr}_{1-1.5 x} \mathrm{Bi}_{x} \mathrm{MoO}_{4}$. As a result, in the range of $\sim 303-573 \mathrm{~K}$ the $\operatorname{tg} \delta$ rises by approximately one order (Fig. 6). It is consistent with the increase of oxygen ion conductivity associated with structural changes.

The $\operatorname{tg} \delta v s$ frequency dependences of all compositions of substituted $\mathrm{SrMoO}_{4}$ indicate that effective dielectric properties are observed at frequency above $1 \mathrm{MHz}$, i.e. in the microwave range, as well

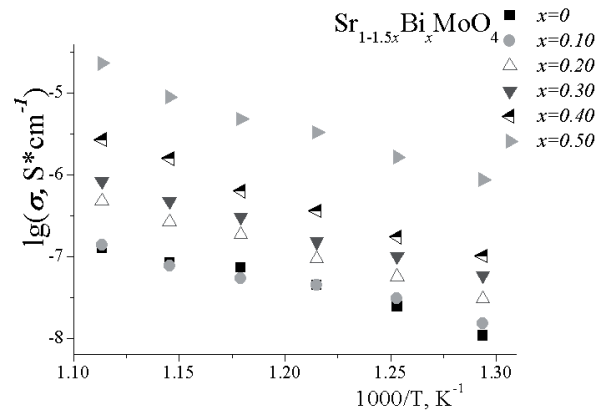

Fig. 4. Arrhenius plots for selected $\mathrm{Sr}_{1-1.5 \mathrm{x}} \mathrm{Bi}_{\mathrm{x}} \mathrm{MoO}_{4}$ compositions

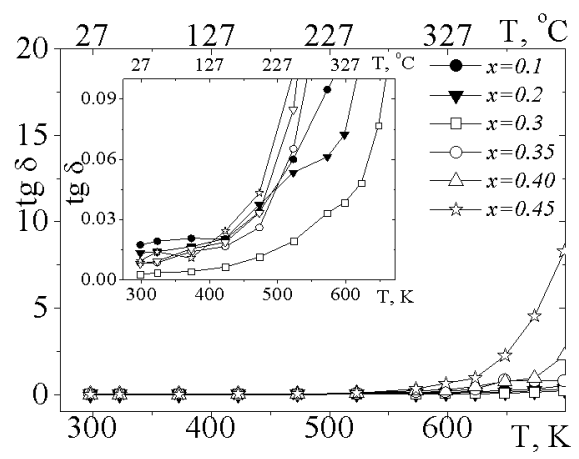

Fig. 5. The $\operatorname{tg} \delta$ vs temperature curves of $\mathrm{Sr}_{1-1.5 x} \mathrm{Bi}_{x} \mathrm{MoO}_{4}$ compositions at $1 \mathrm{kHZ}$

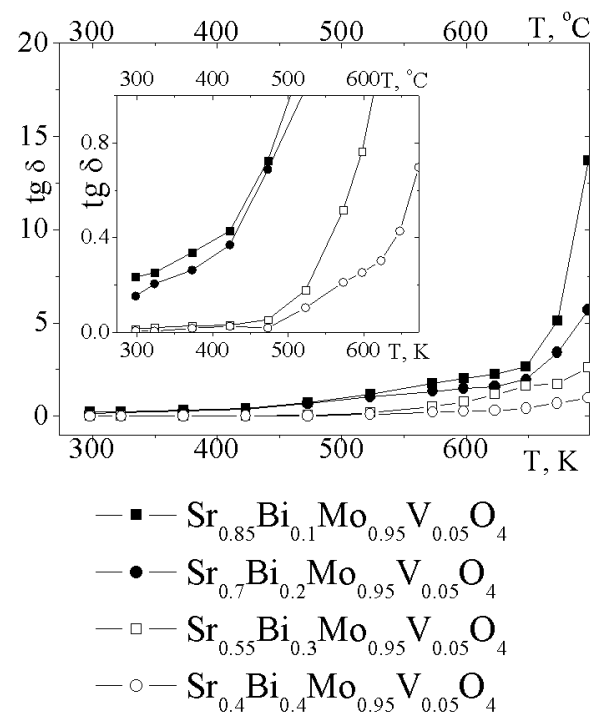

Fig. 6 . The tg $\delta v s$ temperature curves of several $\mathrm{Sr}_{1-1.5 \mathrm{x}} \mathrm{Bi}_{\mathrm{x}} \mathrm{Mo}_{1-\mathrm{y}} \mathrm{V}_{\mathrm{y}} \mathrm{O}_{4-\mathrm{d}}$ compositions at $1 \mathrm{kHZ}$ 
as $\mathrm{CaMoO}_{4}$ - based dielectric materials [16] (the example is given in Fig. 7).

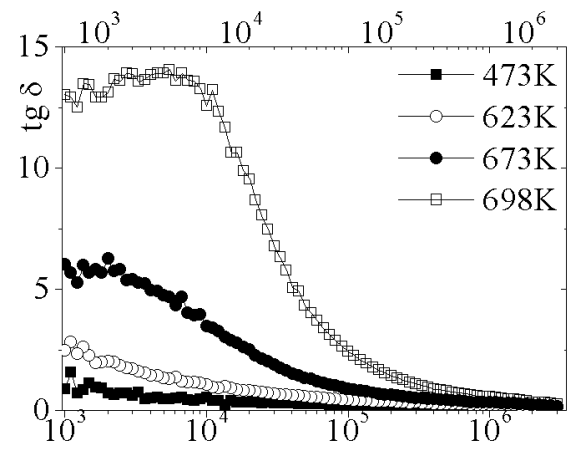

Fig. 7. The tg $\delta v s$ frequency curves of $\mathrm{Sr}_{0.7} \mathrm{Bi}_{0.2} \mathrm{Mo}_{0.9} \mathrm{~V}_{0.1} \mathrm{O}_{4-d}$

\section{Conclusions}

Thus, the present research demonstrates the existence of cationic-deficient sheeliterelated complex oxides of $\mathrm{Sr}_{1-1.5 x} \mathrm{Bi}_{x} \mathrm{MoO}_{4}$ series and $\mathrm{Sr}_{1-1.5 x} \mathrm{Bi}_{x} \mathrm{Mo}_{1-y} \mathrm{~V}_{y} \mathrm{O}_{4-d}$ series. In $\mathrm{Sr}_{1-1.5 x} \mathrm{Bi}_{x} \mathrm{MoO}_{4}$, superstructural ordering is observed for $0.2<x \leq 0.4$. For $\mathrm{Sr}_{1-1.5 x} \mathrm{Bi}_{x} \mathrm{Mo}_{1-y} \mathrm{~V}_{y} \mathrm{O}_{4-d}$ series a changing in oxygen sublattice is assumed. Both of the com- plex oxide series show dielectric properties at temperatures below $503 \mathrm{~K}$ and frequencies above $1 \mathrm{MHz}$. Conductivity and tangent of dielectric loss for $\mathrm{Sr}_{1-1.5 x} \mathrm{Bi}_{x} \mathrm{Mo}_{1-y} \mathrm{~V}_{y} \mathrm{O}_{4-d}$ compositions is greater than for $\mathrm{Sr}_{1-}$ ${ }_{1.5 x} \mathrm{Bi}_{x} \mathrm{MoO}_{4}$. It is consistent with the increase of oxygen ion conductivity associated with mentioned structural changes.

\section{Acknowledgements}

This work was financially supported by grant of Russian Foundation for Basic Research, project № 16-33-60026.

\section{References}

1. Mikhailik VB, Kraus H, Miller G, Mykhaylyk MS, Wahl D. Luminescence of CaWO $\mathrm{CaMoO}_{4}$, and $\mathrm{ZnWO}_{4}$ scintillating crystals under different excitations. J. Appl. Phys. 2005:97(8):083523. DOI: 10.1063/1.1872198.

2. Faure N, Borel C, Couchaud M, Basset G, Templier R, and Wyon C. Optical properties and laser performance of neodymium doped scheelites $\mathrm{CaWO}_{4}$ and $\mathrm{NaGd}\left(\mathrm{WO}_{4}\right)_{2}$. Appl. Phys. B: Lasers Opt. 1996:63(6):593-98. DOI: 10.1007/BF01830998.

3. Sharma N, Shaju KM, Rao GVS, Chowdari BVR, Dong ZL, White TJ. Carbon-Coated Nanophase $\mathrm{CaMoO}_{4}$ as Anode Material for Li Ion Batteries. Chem. Mater. 2004:16 (3):504-12. DOI: $10.1021 / \mathrm{cm} 0348287$.

4. Cavalcante LS, Longo VM, Sczancoski JC, Almeida MAP, Batista AA, Varela JA, Orlandi MO, Longo E, Liu MS. Electronic structure, growth mechanism and photoluminescence of $\mathrm{CaWO}_{4}$ crystal. Cryst. Eng. Comm. 2012:14(3):853-68. DOI: 10.1039/C1CE05977G.

5. Yao WF, Ye JHJ. Photophysical and photocatalytic properties of $\mathrm{Ca}_{1-x} \mathrm{Bi}_{x} \mathrm{~V}_{x}$ $\mathrm{Mo}_{1-x} \mathrm{O}_{4}$ solid solutions. Phys. Chem. B. 2006:110(23):11188-95. http://dx.doi. org/10.1021/jp0608729. 
6. Choi GK., Kim JR., Yoon SH., Hong KS. Microwave dielectric properties of scheelite $(\mathrm{A}=\mathrm{Ca}, \mathrm{Sr}, \mathrm{Ba})$ and wolframite $(\mathrm{A}=\mathrm{Mg}, \mathrm{Zn}, \mathrm{Mn}) \mathrm{AMoO}_{4}$ compounds. J. Eur. Ceram. Soc. 2007:27(8-9):3063-67. DOI: 10.1016/j.jeurceramsoc.2006.11.037.

7. Esaka T, Mina-ai T, Iwahara H. Oxide ion conduction in the solid solution based on the scheelite-type oxide PbWO4 // Solid State Ionics: 1992:57(3-4): 319-25. DOI: 0.1016/0167-2738(92)90165-L

8. Zhang GG., Fang QF., Wang XP., Yi ZG. Dielectric relaxation study of $\mathrm{Pb}_{1-\mathrm{x}} \mathrm{La}_{\mathrm{x}} \mathrm{MoO}_{4+\delta}$ $(\mathrm{x}=0-0.3)$ oxide-ion conductors. J. Phys.: Condens. Matter. 2003:15(24): 4135-42. DOI: $10.1088 / 0953-8984 / 15 / 24 / 307$.

9. Cheng J, Liu C, Cao W, Qi M, Shao G. Synthesis and electrical properties of scheelite $\mathrm{Ca}_{1-\mathrm{x}} \mathrm{Sm}_{\mathrm{x}} \mathrm{MoO}_{4+\mathrm{d}}$ solid electrolyte ceramics. Mat. Res. Bull. 2011:46(2):185-89. DOI: 10.1016/j.materresbull.2010.11.019.

10. Md. Haque M., Kim D-K. Luminescent properties of Eu activated $\mathrm{MLa}_{2}\left(\mathrm{MoO}_{4}\right)_{4}$ based ( $\mathrm{M}=\mathrm{Ba}, \mathrm{Sr}$ and $\mathrm{Ca})$ novel red-emitting phosphors. Mater. Lett. 2009:3(910):793-96. DOI: 10.1016/j.matlet.2009.01.018.

11. Jiang P., Gao W., Cong R., Yang T. Structural investigation of the A-site vacancy in scheelites and the luminescence behavior of two continuous solid solutions $\mathrm{A}_{1-1.5 \mathrm{x}} \mathrm{Eu}_{\mathrm{x}} \square_{0.5 \mathrm{x}} \mathrm{WO}_{4}$ and $\mathrm{A}_{0.64-0.5 \mathrm{y}} \mathrm{Eu}_{0.24} \mathrm{Li}_{\mathrm{y}} \square_{0.12-0.5 \mathrm{y}} \mathrm{WO}_{4}(\mathrm{~A}=\mathrm{Ca}, \mathrm{Sr} ; \square=$ vacancy). Dalton Trans. 2015:44(13):6175-83. DOI: 10.1039/c5dt00022j.

12. Tomaszewicz E, Kaczmarek SM, Fuks H. New cadmium and rare-earth metal molybdates with scheelite type structure // Mater. Chem. Phys. 2010:122(2-3):595-601. DOI: 10.1016/j.matchemphys.2010.03.052.

13. Su Y, Li L, Li G. Synthesis and optimum luminescence of $\mathrm{CaWO}_{4}$-based red phosphors with codoping of $\mathrm{Eu}^{3+}$ and $\mathrm{Na}^{+}$. Chem. Mater. 2008:20(19):6060-67. DOI: $10.1021 / \mathrm{cm} 8014435$.

14. Sameera S, Prabhakar Rao P, Divya S, Raj KV, Aju Thara TR. High IR reflecting $\mathrm{BiVO}_{4}-\mathrm{CaMoO}_{4}$ based yellow pigments for cool roof applications. Energ. Buildings. 2017:154:491-98. DOI: 10.1016/j.enbuild.2017.08.089.

15. Sleight AW, Aykan K, Rogers DB. New nonstoichiometric molybdate, tungstate, and vanadate catalysts with the scheelite-type structure. J. Solid State Chem. 1975:13(3):231-36. DOI: 10.1016/0022-4596(75)90124-3.

16. Guo J, Randall CA, Zhang G, Zhou D, Chen Y, Wang H. Synthesis, structure, and characterization of new low-firing microwave dielectric ceramics: $\mathrm{Ca}_{1-3 \mathrm{x}} \mathrm{Bi}_{2 \mathrm{x}} \Phi_{\mathrm{x}} \mathrm{MoO}_{4}$. J. Mater. Chem. C. 2014:2(35):7364-72. DOI: 10.1039/c4tc00698d.

17. Shannon RD. Revised effective ionic radii and systematic studies of interatomic distances in halides and chalcogenides. Acta Cryst. 1976;A32:751-67. DOI: 10.1107/S0567739476001551.

18. Basiev TT, Sobol AA, Voronko YK, Zverev PG. Spontaneous Raman spectroscopy of tungstate and molybdate crystals for raman lasers. Opt. Mater.2000:15(3):205-16. DOI: 10.1016/S0925-3467(00)00037-9.

19. Cho Y, Bull Y. Fine-tuning the emission color of a transparent suspension of Sr$\mathrm{MoO}_{4}: \mathrm{Eu}^{3+}, \mathrm{Tb}^{3+}$ nanophosphors. Korean Chem. Soc. 2015:36(1):282-86. DOI: 10.1002/bkcs.10065. 